the teaching of international relations. Vernon Van Dyke served as director, and James Murray as assistant director. Schuyler Wallace of Columbia University and Richard C. Snyder of Princeton University served as advisers in planning the program and selecting the participants. Fellowships permitting participation were awarded to the following professors, all teaching in the international relations field: Winston W. Benson, Mankato State Teachers College; Frank R. Brandenburg, University of Pennsylvania; Henry C. Bush, Hunter College; John L. Chase, Louisiana State University; Michael J. Flack, Vassar College; Wallace B. Graves, DePauw University; Clifford P. Ketzel, University of Kansas; John H. McDonough, Georgetown University; Keith S. Petersen, University of Arkansas; John W. Schwada, University of Missouri; Fred A. Sondermann, Colorado College; and Urban G. Whitaker, San Francisco State College.

The general purpose of the seminar was to give the members an opportunity to improve their teaching of international relations. The group focused on the general international politics course. Seminar sessions were devoted to (1) an analyais and appraisal of various approaches to the field, (2) an examination of the meaning and usefulness of various concepts, (3) the appraisal of various texts, (4) an examination of the contributions of various disciplines to the study of international relations, and (5) the development of course outlines. Many of the seminar sessions were led by visiting consultants, including Oliver Benson of the University of Oklahoma, John Gange of the University of Virginia, Harold Guetzkow of the Carnegie Institute of Technoology, Klaus Knorr of the Center of International Studies at Princeton University, Hans Morgenthau of the University on Chicago, Philip E. Mosely of the Council of Foreign Relations, Frederick L. Schuman of Williams College, Richard C. Snyder of Princeton University, and Quincy Wright of the University of Chicago.

On June 14, 1955, the department of political science of the University of Oregon conducted the Third Institute on Management in Government and Business at the Portland Extension Center. This institute examined some of the major problems affecting business and governmental enterprises in the region. Dr. Edwin G. Nourse, formerly chairman, Council of Economic Advisors, delivered the principal address in the institute.

\title{
OTHER ACTIVITIES
}

Contracts for work in public administration in Latin America have recently been signed by the University of Tennessee. One such contract has been entered into by the University of Tennessee and the Universidad Mayor de San Andres of La Paz, Bolivia, under the sponsorship of the International Cooperation Administration, whereby the Bureau of Public Administration of the University of Tennessee will establish in $\mathrm{La} \mathrm{Paz}_{\mathrm{a}}$ Center for Public Administration. The center will provide in-service training for public officials, develop a library, and offer research and consultative service. Six technicians from the United States will be sent to La Paz, and San Andres University will provide additional personnel. Bolivian officials will be sent to the United States for periods of training. A separate contract between the University of Tennessee and the International Cooperation" Administration provides that the Bureau of Public Administration will maintain a team of three technicians in Panama to provide consultative service in cooperation with the U.S. Mission to Panama. Professor Robert S. Avery will head the party to Bolivia and Mr. Edmund Meisenhelder will head the Panama group. Professor Salo Engel will go to Panama to prepare a Panamanian code. Professor Nelson Robinson will go to Bolivia early in January, 1956. Professor Lee S. Greene will serve as coordinator of both contracts at the University of Tennessee.

A short-term Research Program on the History of the CPSU has been inaugurated by an inter-university committee of scholars, consisting of Merle Fainsod (Harvard University), Harold H. Fisher (The Hoover Institute and Library), Philip E. Mosely (New York City), and Geroid T. Robinson (Columbia University), with the financial support of the Ford Foundation.

In order to promote the systematic and expeditous completion of studies relevant to the history of the Communist Party of the Soviet Union, the committee is now able to offer modest grants in aid of research along the following lines: (1) a limited number of fulltime fellowships, pre-doctoral and post- 
doctoral, on a one-year basis, particularly to facilitate the completion of pertinent research projects which are already well underway (as a rule, the program will not be able to support research projects in their beginning stage); (2) grants for a semester, relieving recipients completely of their academic duties for that period and enabling them to devote the period to the completion of research work that was previously well advanced; (3) assistance in securing access to otherwise inaccessible research materials; (4) a limited number of summer grants for subsistence and travel to facilitate access to sources and completion of manuscripts already in an advanced stage.

Applications will be considered from academically trained persons and from other persons who, by their previous research, have demonstrated a high level of competence in this field of investigation. Each applicant should sumbit a detailed statement on (a) the purpose, scope, and original contributions of his study, together with (b) a realistic estimate of the amount of work and support needed to complete it, and also (c) the names of persons best qualified to comment on his competence and on his projects. Requests for application forms and any other correspondence should be addressed to: Research Program on the History of the CPSU, 401 West 118th Street, New York 27, New York.

The government department at the University of Miami has entered into relations with the City of Miami and Dr. John Miklos, Director of Employee Training, to conduct special courses in public personnel administration for the city department heads. A more comprehensive training program has been planned covering other aspects of administration, including courses in management, public relations, effective speaking, and others.

A team of four members of the department of government at the University of Miami, Professors Larson, Serino, Sofen, and Wood, are conducting an impact study for the Miami Municipal Board.

The department of political science at Emory University announces the inauguration of its Ph.D. program in September, 1956.

In September the first 14 graduate students from Thailand arrived at Indiana University under the Indiana University-Thammasat University Public Administration Program financed jointly by the governments of the United States and Thailand. This is the first of several groups to be sent from Thailand in the course of a three-year period. These students are enrolled in a two-year M.A. program designed to prepare them for teaching and research postions in the newly established Institute of Public Administration at Thammasat University. In residence at the Institute of Public Administration in Bangkok this year are the following members of the Indiana University department of government: Joseph L. Sutton, chief of party and director of research; Joseph B. Kingsbury, professor of public administration; and John W. Ryan, research associate. Both the Minister of Education, H. E. General Promyothi, and the new director of the institute, Dean Malai Huvanandana, visited Indiana University during September and October to discuss program plans.

The National Association of County Officials has granted Indiana University's department of government $\$ 1,250$ as a fellowship to study rural road administration. The fellowship has been awarded to Mr. Robert Adang, a graduate student in government.

The political science department of the State University of Iowa is continuing its experiment with the use of closed circuit television. Following a successful "trial run" with a course in comparative government last spring (see this Revrew, Vol. 49, pp. 932-33, Sept., 1955), a group of 85 students in the beginning course in American government are now being taught with the use of television by Professor James N. Murray, Jr. The test scores of this class will be compared with the scores of students in a large class of about 200 and those of two smaller classes of 15 or 20 students each to be taught without television during the spring semester of the current year.

As a part of the experiment in teaching political science through the use of mass media at the State University of Iowa, Donald Bruce Johnson is broadcasting the course in American government over radio station WSUI during the fall semester.

The University of Massachusetts announces the establishment of a Bureau of Government Research. This agency, for which legislative authorization was made at the last session of the General Court, will conduct studies of 
local and state government and will carry on other activities usually associated with such organizations.

At Ohio Wesleyan University, the Institute of Practical Politics has been named the "Ben A. Arneson Institute of Practical Politics" in honor of its founder and director, who retired in 1953. Professor Earl Warner of the department of political science has been appointed director, and $\mathrm{Mr}$. William H. Eells is serving as executive officer. Financial support for the institute has been obtained from the Maurice and Laura Falk Foundation.

The department of political science of Ohio Wesleyan University, aided by a grant from the Maurice and Laura Falk Foundation to its Arneson Institute of Practical Politics, conducted a summer workshop on the problem of the introductory course. Participants included Professors Earl Warner, Robert Lorish, Victor Walter, and William Strachan (emeritus) of the department, Professor Lloyd Easton (philosophy), and Professor Chester Mathews (education). Professor E. Allen Helms of Ohio State University served as a consultant. The resulting course, called "Introduction to Government and Politics," is designed to introduce the student to the fundamental principles of political science, to provide a broad understanding of the American and other systems of government, to develop political intelligence and tolerance, and to stimulate interest in politics. Recognizing the difficulties in attempting to attain these objectives in the traditional three class periods per week, the course is so organized that the student is required to fill in much of the content by means of individual term projects outside the classroom. To aid in this task, two undergraduate assistants have been assigned to each section to guide, tutor, or offer remedial services to the students and to supervise the term projects. Class discussions are based primarily on materials taken from Wit's Comparative Political Institutions and Ebenstein's Todoy's Isms. Appointments to the assistantships were made not only on the basis of demonstrated ability in the field, but also with reference to the students' interest in the possibility of becoming college teachers. It is hoped that an important by-product of the program will be the encouragement of a larger proportion of the abler political science majors to prepare for the college teaching profession.
The Woodrow Wilson Department of Foreign Affairs at the University of Virginia, in cooperation with the Woodrow Wilson Foundation, sponsored an address by Adlai Stevenson on November 11, 1955. This address was a preliminary function for the Woodrow Wilson Centennial which begins December 28, 1955 and extends to December 28, 1956.

The Bureau of Government at the University of Wisconsin has been asked by the Legislative Council to make a study of the alternative forms of county and local government that might be suitable for the Menominee Indian Reservation when it comes under state control on January 1, 1959. The study will explore the governmental arrangements now existing in the area and will analyze the feasibility of the other kinds of arrangements. The study is being done for the bureau by Professor Lloyd W. Woodruff, assistant director of the bureau.

Ralph Braibanti, of Duke University, gave a series of four lectures on Japanese government at the Foreign Service Institute of the Department of State in August. In October Professor Braibanti lectured on Asian international relations to branches of the Canadian Institute of International Affairs in Ottawa, Montreal, Quebec City, Sherbrooke, Fredericton, and Halifax.

George Catlin will deliver a series of lectures at Hamline University, Macalester College, St. Paul, Minnesota, on the Hill Memorial Foundation bequest.

Taylor Cole, of Duke University, spent the past summer visiting universities in Australia, New Zealand, and the Union of South Africa in connection with the Duke University Commonwealth Studies Center.

James C. Coleman, University of California at Los Angeles, participated in the TwentyNinth Study Session of the International Institute of Differing Civilisations, held in London, England, September 13-16. The theme of the session was "The Development of a Middle Class in Tropical Countries."

Andrew Gyorgy, professor of government at Boston University, lectured on "Soviet Foreign Policy" at the Universities of New Brunswick and Nova Scotia, Oetober 1-6, 
1955 , under the auspices of the Canadian Institute of International Relations.

During the past summer Rodney L. Mott, director of the division of social sciences and professor of political science at Colgate University, served as a public member of a State Department Ninth Selection Board. These boards are established under the Foreign Service Act to review the performance of Foreign Service Officers in American embassies and consulates and to make recommendations to the Secretary of State for promotions.

James K. Pollock, chairman of the department of political science at the University of Michigan, was elected President of the International Political Science Association at the 1955 conference held in Stockholm.
Robert S. Rankin, of Duke University, spent part of the past summer in Canada doing research on the administration of Canadian grants-in-aid.

Clinton Rossiter, professor of government at Cornell University, delivered the principal address at the Sixty-Eighth Founders Day Convocation at Pomona College on October 13, 1955. His subject was "The Liberal Arts College in American Society." During his visit to Pomonā College, Professor Rossiter made two other addresses on "The Origin of the American Tradition" and "The Age of Eisenhower."

Robert Sealapino, of the University of California (Berkeley), spent the summer months in Japan and Southeast Asia engaged in area research.

\section{APPOINTMENTS AND STAFF CHANGES}

Milton C. Abrams, who is serving as librarian in the Institute of Government at the University of Utah while working toward a Ph.D. degree, has been appointed Director of Libraries at Utah State Agricultural College, Logan, Utah. He will assume his duties there next year.

Robert E. Agger, who spent last year at the Center for Advanced Study in the Behavioral Sciences at Stanford University, has returned to the University of North Carolina.

Ethan P. Allen, chairman of the department of political science at the University of Kansas, has been appointed to the Governor's Advisory Committee on Revenue and Taxation. Professor Allen has also been named to the Executive Committee of the Missouri Basin Research and Development Council.

Paul S. Bachman has been appointed President of the University of Hawaii, effective September 1, 1955.

Chester W. Bain has been appointed assistant professor of political science at the University of Virginia. He will continue to serve as research assistant in the Bureau of Public Administration.

Richard C. Baker, formerly of Drake University, has been appointed associate professor of political science at Harding College.
Edward Banfield, formerly assistant professor in the Planning Committee at the University of Chicago, has been appointed assistant professor of political science at that institution.

Ernest R. Bartley of the department of political science at the University of Florida, has been promoted to full professor. Professor Bartley was a consultant to the Public Administration Service of Chicago and the Alaska Statehood Committee while on leave from July to September 15, 1955. He is serving as director of research for the Florida Constitution Advisory Commission in Tallahassee, in addition to his teaching duties.

George A. Bell, who received his $\mathrm{Ph}$.D. at the University of Michigan, has been appointed research associate in the Bureau of Governmental Research at the Univeristy of Maryland, effective September 1.

Frederick T. Bent, who recently returned to the United States after four years at the American University of Beirut, Lebanon, has been appointed assistant professor of political science at Coe College, Cedar Rapids, Iowa.

Charles Blitzer, assistant professor of political science, Yale University, has returned after a year's leave of absence in England.

Rosalind L. Branning has been promoted to 